\title{
THE IMPORTANCE OF THE ATMOSPHERE OF THE ENVIRONMENT IN BRAZILIAN PHYSICAL RETAIL IN 2030
}

\author{
A IMPORTÂNCIA DA ATMOSFERA DO \\ AMBIENTE NO VAREJO FÍSICO \\ BRASILEIRO EM 2030
}

Submission: $14 / 01 / 2019$ Accept: 01/02/2020

\author{
Sidney de Aguiar Neves ${ }^{1}$ \\ Mauricio Jucá de Queiroz ${ }^{2}$ \\ Renata Steffanoni Bernardes de Queiroz ${ }^{3}$ \\ Luis Fernando Ascenção Guedes ${ }^{4}$
}

\section{ABSTRACT}

In the face of the technological developments, the change in consumer behavior and the intensification of the use of the internet in the purchase of products and services, it is identified the need to develop new competitive structure in the Brazilian physical retail. In this context, the atmosphere of the environment has been adopted as an important strategic tool in physical retail in order to provide competitive advantage and consolidate the consumer's shopping experience. This article seeks to identify trends related to the atmosphere of the Brazilian physical retail environment in 2030. The research developed in this article started from an exploratory approach with qualitative nature and it was divided into two stages: one, involving eight retail executive professionals (Vision 1), with data collection through the Survey Monkey platform electronic questionnaire; the second stage was conducted face-to-face and Skype semi-structured interviews with four retail executive professionals (Vision 2). It was possible to identify: a) the factors that will affect the atmosphere of the environment; b) the factors that need change for physical retail to serve the consumer; $c$ ) the most important relationships between physical retail versus the consumer; $d$ ) the dimension of greatest value to the consumer and e) as regards behavior.

Keywords: Environment atmosphere; value perception; consumer behavior; experiential marketing.

\footnotetext{
1 Graduated in Civil Engineering (UGF/RJ), he has an MBA from FIA Business School, and is currently a master's student in the Professional Master's Program of the FIA Business School. São Paulo - SP, Brazil. E-mail: bsbengenharia@hotmail.com ORCID: https://orcid.org/0000-0002-6519-0373

$2 \mathrm{PhD}$ in Business Administration from the University of São Paulo (2008), Master in Business Administration from the University of São Paulo (2004), Graduated in Business Administration from the University of São Paulo (1994). He is currently Dean of Faculdade FIA de Administração e Negócios located in São Paulo and also coordinates the undergraduate course in Business Administration. São Paulo. Brazil. E-mail: mauricioj@fia.com.br ORCID: https://orcid.org/0000-0002-5905-5730

$3 \mathrm{PhD}$ in Communication from the School of Communication and Arts at the University of São Paulo, Master in Business Administration from the Faculty of Economics, Administration and Accounting at the University of São Paulo and a degree in Economics from the same institution. Currently Coordinator of Research and Scientific Initiation Facamp - Campinas, institution in which coordinated the course of Advertising and Marketing for 2 years. São Paulo. Brazil. E-mail: renata.queiroz@facamp.com.br ORCID: https://orcid.org/0000-0003-4297-7218 4 PhD in Business Administration from the University of São Paulo (2012), Master in Business Administration from EAESP/FGV (2004). Graduated in Electrical Engineering from FEI (1995). He is currently a professor from Undergraduate Course and Professional Master Program in Business Management at FIA. E-mail: luisf@fia.com.br ORCID: https://orcid.org/0000-0002-1335-9122
} 


\section{RESUMO}

Diante das evoluções tecnológicas, da mudança do comportamento do consumidor e da intensificação do uso da internet na aquisição de produtos e serviços, identifica-se a necessidade de desenvolvimento de novas estrutura competitiva no varejo físico brasileiro. Nesse contexto, a atmosfera do ambiente passou a ser adotada como importante ferramenta estratégica no varejo físico a fim de proporcionar vantagem competitiva e consolidar a experiência de compra do consumidor. Este artigo busca identificar quais as tendências relacionadas à atmosfera do ambiente no varejo físico brasileiro em 2030. A pesquisa desenvolvida neste artigo partiu de uma abordagem exploratória com cunho qualitativo e foi dividida em duas etapas: uma primeira, envolvendo oito profissionais executivos de varejo (Visão 1), com a coleta de dados feita por meio de questionário eletrônico da plataforma SurveyMonkey; a segunda etapa, realizada com entrevistas semiestruturadas presenciais e via Skype com quatro profissionais executivos do varejo (Visão 2). Em seguida foram identificados a) os fatores que impactarão a atmosfera do ambiente; b) os fatores que necessitam de mudança para que o varejo físico atenda ao consumidor; c) as relações mais importantes entre o varejo físico versus o consumidor; d) a dimensão de maior valor para o consumidor e e) quanto ao comportamento.

Palavras-chave: atmosfera do ambiente, percepção do valor, comportamento do consumidor, marketing experiencial.

\section{INTRODUCTION}

Gilles Lipovetsky, researcher and professor at the University of Grenoble, studies the so-called "hypermodernity", a phenomenon that involves, among other principles, what is called "hyperconsumption", that is, the increasing the purchase of goods and services by modern society. Lipovetsky (2010) divides the "new historical stage of consumer civilization" into three phases:

1) phase 1 - which begins around 1880 and ends with World War II, in which small local markets are shifted by large national markets, made possible by transport and communication infrastructure. It was at this stage that mass marketing and the modern consumer were invented;

2) phase 2 - which started around 1950, when there was intense global economic growth, called the "society of abundance" phase, which the author describes as the "pure period of mass consumption society";

3) phase 3 - which started between the late 1970 s and early 1980s, it is time for "hyperconsumption", the extreme diversification of the supply of products and services, the trivialization of access to novelties and making consumers "less predictable and more volatile", desiring objects "to live"and "to display". Consumers were more oriented towards individual tastes and criteria.

The observed changes in behavior, with technological developments promoted by the Internet, further has evidenced hyperconsumption. The need for more information on products, processes and services has brought up new parameters for assessing the outcome of consumption of goods and services, as well as creating a new dynamic in the process of purchasing decision of individuals. These new parameters allowed consumers to use multiple platforms and channels during their buying journey. Individuals want to decide how and where to buy, making little distinction between physical or digital environment.

Mattar (2011) presents the three major concerns of physical retailers regarding the new forms of marketing of products and services promoted by the internet. The first concern is the speed with which electronic retail grows and reaches specific market segments. The second is associated with the fact that small percentages of lost market share in low-margin and competitive sectors can mean a significant reduction in the number of stores in physical retail. Finally, the author reinforces the difficulty in competing with electronic retail, as it offers several benefits and advantages to the consumer. 
These factors enable multichannel management, defined as the use and articulation of multiple channels by the retailer to bring their goods to final consumers. It is clear that multichannel retail does not only cover physical stores and the Internet, but a whole set of possible forms of sale, such as telemarketing, direct selling, catalog purchases and the combination of different forms of delivery to end consumers. (SIQUEIRA, 2004).

In this scenario, Verhoef, Kannan and Inman (2015) argue that it is fundamental for retail management to understand the consumer's buying journey by naturally integrating online and offline (physical and virtual) means, both in the search for information and in making purchases. For the authors, companies face new challenges that stem from the Multichannel strategy for Omnichannel management development, because even with certain similarities in the use of various channels there are differences in priorities in their management. While Multichannel prioritizes marketing channels for increased presence, Omnichannel places more emphasis on interactions between channels and brands. In this sense, the store environment also becomes important from Omnichannel management, as it also considers the interactions between the consumer and the brand within the channels, creating differentiated shopping experiences in both physical and virtual environments (VERHOEF, et al, 2015; BRYNJOLFSSON, et al, 2013). However, it is argued that this change requires organizations to work closely with their customers to understand their businesses and environments. Nowadays, consumers are immersed in a wide and complex variety of networks, so that technology (internet) enables these connections and facilitates many types of interactions (VERHOEF et al., 2017). Thus, the increase of innovation in retail technology caused changes in consumer behavior (WOOD, 2002).

In this context the retail market must take into account the changes in consumer behavior, social and technological trends, which cause constant changes in market preferences and demand strategic choices as to the innovations and management models to be adopted (DE ANGELO; NIELSEN; FOUTO, 2012).

De Angelo, Nielsen and Fouto (2012) also highlight that:

Consumers are becoming less and less loyal to traditional consumption patterns, which impacts sales channels, products and brands. People are always looking for products with new features and differentiations. In contrast, companies are constantly in need of innovating to remain competitive in the markets they operate (DE ANGELO; NIELSEN; FOUTO, 2012, pg. 60).

The first to coin a definition of retail atmosphere was Kotler (1973), with the publication of the article "Atmospheric as a Marketing Tool". In this paper, Kotler introduced the concept of store environment influence on consumer perception and behavior, developing the term store atmosphere.

The central idea of this concept concerns how the atmosphere of the environment can influence the consumer's decision to buy from a pleasant space, increasing his permanence and encouraging him to consume the product offered and inducing him to return whenever he needs it. This product and / or service.

In addition, Bitner (1992) states that customer well-being results not only from the product consumed, but from the environment that generates consumer perceptions that will influence the decision making process and purchase intention (BITNER, 1992).

There are many variables and factors that make up the store atmosphere. An atmosphere requires care and attention to the intended audience, as people have different reactions to a particular stimulus. Thus, the various actions related to the store's atmosphere have to align with the company's strategic program to produce the desired effect (GONZÁLEZ-BENITO; MUÑOZ-GALLEGO; KOPALLEB, 2005; TURLEY, CHEBAT, 2002). These authors establish a definition 
of store atmosphere or service atmosphere or service scenario with virtually the same sets of characteristics or stimuli. The term "environment atmosphere" will be adopted for this work, as it has expressiveness in relation to the physical retail sector.

\section{THEORETICAL FRAMEWORK}

\subsection{Physical Retail}

According to Kotler and Keller (2012), retail includes the sale of goods and services designed directly to the final consumer. So any organization that sells to end consumers is involved in retail - manufacturers, distributors, wholesalers or retailers - looking at the various forms and new reality of retail marketing. Different store formats (physical or virtual) will have different competitive dynamics, including differentiated service levels, store environment, pricing, communication, as well as activities and building experiences, seeking to meet and satisfy certain consumer groups.

Retail combines numerous variables, such as store format and location, product and service mix, price, ambiance and layout. It also adopts various communication tools, ranging from showcases, displays, totems, sales promotion, product experimentation and elements and communication, which ensure important influence and leads to consumer buying decision (QUEIROZ, 2015).

As the store environment is adjusted to the intended audience and aligned with the organization's strategic planning, the variables that make up this ambience are important factors for market segmentation. Thus, the plan defined by retail to serve its public depends on the format of the store and this represents the company's strategy determining its competitive structure (GONZÁLEZ-BENITO; MUÑOZ-GALLEGO; KOPALLE, 2005).

Retail as a function is central to all economies: it unites diverse consumer shortcomings with specialized product offerings. Retail functions comprise assortment creation, physical merchandise logistics, legal transactions with the consumer, general information provision and communication, and the provision of ancillary services. Retail as a function is part of the retail value chain. In its most substantial form, this value chain includes manufacturing (brand) manufacturers, institutional retailers, and consumers, with institutional retail referring to agents whose sole or major benefits come from conducting retail activities (REINARTZ et al., 2019).

\subsection{Environment Atmosphere}

According to Laksono (2013), the store atmosphere has become one of the determining factors of consumer expectations and also represents an important stimulus to consumers' experience in physical store buying situations.

Underhill (2009) comments that many consumers are influenced or carry out their decision making process in the internal store environment. However, given the dynamic and competitive environment, it is up to the retailer to identify a competitive advantage that characterizes a differential and promotes consumer attractiveness (UNDERHILL, 2009).

Studies conducted by Ferreira et al. (2006), Milan (2007) and Verde, Arruda and Moura (2007) analyzed the service consumer's experience and his emotional attitude to the environment. This theme is observed from topics such as thematic environment, environmental architecture, service environment in the form of thematic scenario, servicescapes as a service atmosphere or even assuming the characteristics of theatrical stage. 
The atmosphere of a store can act as a differentiation strategy. According to Underhill (2004):

When we first enter a store, our senses are heightened, and our eyes sweep the whole place. We smell the air and our ears look for signals that tell us exactly where we are. All this makes shopping a kind of fun. This is what distinguishes one store from all others (UNDERHILL, 2004).

Mehrabian and Russel (1974) identified the effects caused by the store atmosphere on people's emotions, altering the company's image, customers' purchase intent and store revenue. For them, the physical environment is capable of influencing behavior and image of the establishment, and is particularly important for goods, services and retail companies.

The evolution of physical store formats follows these concepts and creates conditions for the development of a shopping atmosphere that contributes to the consolidation of a differentiated experience for consumers. The atmosphere can still be materialized through diferents variables (colors, lighting, music and aromas) and the combination of multiple sensory capabilities to create a unique atmosphere. Many companies already use these techniques to create unique background music, tailored sounds, lighting, colors, decor, distinctive scent or aroma tailored to each section and consumer profile (MCGOLDRICK, 2002).

In addition, consumer clarity about the service is associated with scenario characteristics, where variables such as light, temperature, odor, noise, music, and various other factors can positively affect satisfaction when well managed (BITNER, 1992; HOLBROOK; GARDENER, 2000; OAK; MOTTA, 2002).

\subsection{The dimensions of the environment atmosphere}

Kotler (1973) addressed this topic long ago, highlighting the importance of creating an environment through the use of color, lighting, sound and furniture to encourage consumers' perceptive and emotional responses and influence their buying behaviors.

The atmosphere of a store is perceived by consumers through the visual and aesthetic elements of the environment that can affect the perception of the quality of the goods themselves sold (RICHARDSON; JAIN; DICK, 1996). Consumers may be even more motivated by the atmosphere lived in the establishment than in their own purchases (MILAN, 2007).

Some authors have developed models by defining dimensions for this atmosphere: Bitner (1992), Kotler (1973), Mehrabian and Russell (1974), Bitner (1992), Baker et al. (2002), Turley and Chebat (2002). All were unanimous in stating that the store atmosphere or retail atmosphere is divided into three dimensions: Environmental, Design and Social. Table 1 presents these models and their characteristics: 
Table1: Models of Application in the Environment Atmosphere

\begin{tabular}{|c|c|}
\hline \multicolumn{2}{|c|}{ MAIN MODELS OF APPLICATION IN THE ENVIRONMENT ATMOSPHERE } \\
\hline AUTHORS & MAIN CHARACTERISTICS \\
\hline Bitner (1992) & $\begin{array}{c}\text { Consumer behavior is related to the environment - } 3 \text { types of behavior: } \\
\text { approach, remoteness and interaction; the author highlights } 3 \\
\text { environmental dimensions: environmental, environmental functionality and } \\
\text { signage and symbols. }\end{array}$ \\
\hline Baker et al (2002) & $\begin{array}{l}\text { Model tested by structural equations; It proposes relationships between } \\
\text { the dimensions of a store's atmosphere (social, design and environmental) } \\
\text { and the perceived value of the goods sold, the cognitive and psychic costs } \\
\text { involved in the process, and the return and recommendation intentions. The } \\
\text { store environment is divided by factors: social factor, design factor and the } \\
\text { environment factor. }\end{array}$ \\
\hline $\begin{array}{l}\text { Turley and Chebat } \\
\text { (2002) }\end{array}$ & $\begin{array}{c}\text { Retail environment design is seen as a competitive advantage; The model } \\
\text { seeks to integrate the atmosphere into the strategic planning process and } \\
\text { creates three stages: it develops overall business strategies and thus houses } \\
\text { a number of controllable variables including the retail atmosphere, design of } \\
\text { a specific retail atmosphere configuration of existing or existing stores, and } \\
\text { involvement of atmospheric design elements capable of generating specific } \\
\text { effects on purchasing behavior. }\end{array}$ \\
\hline $\begin{array}{l}\text { Mehrabian and Russel } \\
\text { (1974) }\end{array}$ & $\begin{array}{l}\text { Adopts environmental psychology for consumer behavior, it responds to sen- } \\
\text { sory stimuli with emotional and behavioral responses - EBR. }\end{array}$ \\
\hline Kotler (1973) & $\begin{array}{c}\text { Causal relationships between store atmosphere and likelihood of purchase: } \\
\text { sensory qualities, buyer's perceptions, effects of sensory qualities - changes } \\
\text { in buyer's affective state and impact of information modification and buyer's } \\
\text { affective state on buyer's likelihood. }\end{array}$ \\
\hline
\end{tabular}

\subsection{The influence of environment atmosphere on value perception}

Understanding the meaning of value in an organization's offering from a customer perspective enables the development, creation, and improvement of marketing strategies in accordance with designated values. The competitive advantage lies in finding new ways to meet customer desires while delivering the highest expected value (WOODRUFF, 1997).

According to Zeithaml (1988), the value perceived by consumers originates in the confrontation between benefit and sacrifice involved in a particular business. Kerin et al. (2007) define that, from the consumer's point of view, price is strongly used to indicate value when compared to the perceived benefits of a product or servisse

The relevance of emotional and affective nature underlies the interaction between the stimuli present in products and the services consumed (HIRSCHMAN; HOLBROOK, 1982). Holbrook (1996) comments that consumer value involves the interrelationship of four value dimensions: (a) interactivity, which concerns the relationship between the consumer and the product; (b) relativism, when there is comparison between objects, people and a specific context; (c) preference, which translates into meanings such as affection, attitude, evaluation, predisposition, opinion, response tendency and valence; and (d) experience that this consumption produces, since the value is not only in the product purchased, nor in the brand chosen or the object possessed. The value generated from this experience in the store atmosphere makes it an attractive and competitive alternative of differentiation for the market (HOLBROOK, 1996). 


\subsection{The experience in the environment atmosphere}

Consumer habits are no longer considered purely rational (ADDIS; HOLBROOK, 2001; SOLOMON, 2002). Emotions, fantasies and aesthetic pleasures are seen as important in the purchase of various types of products, establishing a consumer experience capable of presenting symbolic and subjective benefits to consumers (HIRSCHMAN; HOLBROOK, 1982; HAVLENA; HOLBROOK, 1986).

Amid this transformation in points of sale, there is also a change in the consumer profile. According to Schmitt (2000), consumers are driven by both reason and emotion, and seek to experience shopping experiences and not just get quality products. However, Underhill (2009) states that this new consumer is the one who chooses their brand and product preferences, spending little time on their buying decisions and seeing them as pleasurable purchases made quickly.

The experience shows several aspects, including the environment that represents the point of sale or the place where the service is performed and its influence in the five senses, as mentioned by Bitner (1992), Daucé and Rieunier (2002) and Teixeira e Barbosa (2008). Hetzel (2004) states that the attributes of the experience can be measured by the following indicators: place; architecture; design; staging; environment decoration; physical structure; space organization; storage of tables; lighting; temperature; background music; predominant odors; number, dress, attitudes and reactions of employees; attendance; and interaction with customers.

In the consumer's experience, entertainment and creativity are taken into consideration and are used by the organization as a strategy of attractiveness and aiming to generate value (BERRY; CARBONE; HAECKEL, 2003).

It is noteworthy that today's consumers place more emphasis on the emotional side of experience and that a large number of businesses have responded to this offer in an attempt to gain a competitive edge (SCHMITT, 1999; BAKER et al., 2002; BÄCKSTRÖM; JOHANSSON, 2006; NAYLOR et al., 2008). However, Verhoef et al. (2009) consider that the generation of maximum experience seems to be one of the central objectives of contemporary retail, uniquely in relation to the store atmosphere.

\subsection{Competitive strategy and the atmosphere of the environment}

Today's survival forces companies to build consumer-focused strategies, thus developing an ability to respond and adapt to the needs of their audience. This interaction suggests a true inclusion of the consumer in corporate strategies, and the company determines how the relationship will occur.

In this sense, Perez (2004, p. 133) compares:

(...) if in the preceding phase the brands were nourished and sustained in communication, in the present phase the brand produces meanings and gets closer to the public. The brand proposes to its audiences a share. Consuming Lancôme, for example, means sharing a sweet and romantic feminine view (PEREZ, 2004, p.133).

Competitive differentiation is not just about quality, so the organization must direct internal processes to deliver value aligned with the value perspectives the consumer sees (WOODRUFF, 1997). Puccinelli et al. (2009) state that when retailers admit the need for customer deepening and act on that knowledge, consumer satisfaction increases, as does retail performance and success. 
Store atmosphere becomes a relevant strategic variable that is difficult to copy and an important means of gaining competitive advantage. As a result, benefits can be gained from sales, attraction-rejection behavior, store image, retail entertainment, employee satisfaction, and competitive advantage. For this reason, the store atmosphere should be designed on the basis of a customer-centric strategic planning, based on the understanding of which elements are valued by the consumer in a specific store environment, thus making the atmosphere a important tool of value creation for the consumer (TURLEY; CHEBAT, 2002). They also argue that the store environment is also an important instrument of standardization, being widely used by retail chains and franchises for the constitution of a visual identity (TURLEY; CHEBAT, 2002).

When the product or service is targeted at specific social classe or lifestyle groups, retailers propose the atmosphere so that the store is arranged according to the chosen segment, as different groups act differently to the environment. (KOTLER, 1973; BITNER, 1992).

In some segments, environment specification is the main differentiation in offering products and services that can be found in other establishments. This strategy allows for strong price differentiation (KOTLER, 1973; BAKER et al., 2002; ANDERSSON; MOSSBERG, 2004; PUCCINELLI et al., 2009).

Verhoef et al. (2009) recognize the existence of many types of retailing in which the product or service plays a secondary role, with the store atmosphere being the main attraction and experience being the real reason for the existence of the business.

\section{METHODOLOGICAL PROCEDURES}

The objective of this paper is to develop a vision of the atmosphere of the environment in 2030 facing the technological changes and adjustments necessary to meet the needs of consumers.

As primary research, an exploratory and qualitative approach was adopted. For Gil (2014), an exploratory research seeks to become familiar with a subject little explored or known and its main objective is to determine the field of study. For Sampieri, Collado and Lúcio (2006), when the objective is to examine a problem that is still little studied, exploratory studies are the most indicated.

In this sense, qualitative studies are associated with real situations and are a powerful source of analysis and collection, at certain times and over long periods (GRAY, 2012). Moreover, Ghauri and Gronhaug (1995) and Creswell (2010) state that studies of complex subjects, such as human or organizational behavior, qualitative research is the most suitable.

The present study was conducted in two steps, in order to have a probable atmosphere of the environment in 2030, and the data collection was made from two non-probabilistic samples.

In the first stage, a structured questionnaire was created via SurveyMonkey to obtain the opinion of retail executives. Twenty-two executives from the sector were selected, of which 8 answered the questionnaire. Table 2 presents the sample selected by segment of the retail chain. 
Table 2 - Vision 1 Respondent Profile by Retail Chain Segment

\begin{tabular}{|c|c|c|c|c|}
\hline $\begin{array}{c}\text { RETAIL CHAIN } \\
\text { SEGMENT }\end{array}$ & POSITION & EXPERTISE & GUESTS & RESPONDENTS \\
\hline $\begin{array}{c}\text { Independent Retail } \\
\text { Advisor }\end{array}$ & CEO - Partner & $\begin{array}{c}\text { Physical Retail Consul- } \\
\text { ting }\end{array}$ & 1 & 1 \\
\hline $\begin{array}{c}\text { Chain stores / fran- } \\
\text { chise stores / inde- } \\
\text { pendente store }\end{array}$ & $\begin{array}{c}\text { CEO / Director / Di- } \\
\text { vision Managers }\end{array}$ & Physical Retail & 16 & 6 \\
\hline Shopping Center & Superintendent & Shopping mal retail & 5 & 1 \\
\hline TOTAL & & & 22 & 8 \\
\hline
\end{tabular}

Source: elaborated by the author.

From the analysis of the answers obtained through the questionnaire applied in step 1 , the researcher elaborated an in-depth interview script answered by 4 retail executive professionals, so that they could indicate the probable view of the atmosphere of the physical retail environment until 2030. Table 3 shows the sample selected by skill segment.

Table 3 - Vision 2 respondents profile invited by specialty segment

\begin{tabular}{|c|c|c|}
\hline RESPONDENTS & EXPERTISE & POTISION \\
\hline Respondent1 & Shopping Center/ & Director \& Founder \\
\hline Respondent 2 & Physical Retail & President \\
\hline Respondent 3 & Physical Retail & Founder \\
\hline Respondent 4 & Future/ Innovation/Tendencies & CEO \\
\hline
\end{tabular}

Source: elaborated by the author.

To define the factors applied in the ambient atmosphere, a matrix of integration of the retail space in the ambient atmosphere was elaborated in order to contemplate the aspects of the ambient atmosphere in three dimensions for the analysis of the store environment (environmental, design and social), according to the authors presented in the theoretical framework (Chart 1). Although other factors and variables can be identified to compose the atmosphere of the environment, only 10 were chosen for this research, as they are easily understood by the respondents and strongly perceived by the consumer, according to Chart 1 .

CHART 1: Factors matrix used in the Vision 1 and Vision 2 questionnaire.

\begin{tabular}{|c|c|c|}
\hline \multirow{6}{*}{ 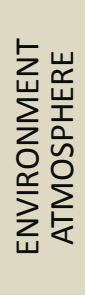 } & \multirow{3}{*}{$\begin{array}{l}\text { ENVIRONMENTAL } \\
\text { DIMENSION }\end{array}$} & TEMPERATURE \\
\hline & & $\frac{\text { MÚSIC }}{2}$ \\
\hline & & ODOR (ESSENCE CHARACTERISTIC \\
\hline & DESIGN DIMENSION & $\begin{array}{c}\text { ARCHITECTURE / FURNITURE / LAYOUT / EXPERIENCE } \\
\text { ATTRACTIVENESS OF FACILITIES / LOCAL }\end{array}$ \\
\hline & & $\begin{array}{c}\text { EMPLOYEES AND THEIR UNIFORMS } \\
\text { SERVICE }\end{array}$ \\
\hline & SOCIAL DIMENSION & $\begin{array}{c}\text { SIGNALING / INFORMATION CONTENT } \\
\text { CONSUMER }\end{array}$ \\
\hline
\end{tabular}

Source: elaborated by the author

\section{AGGREGATE DATA ANALYSIS}

After conducting the research and data collection, the analysis of the results began based on the content analysis of the responses of managers interviewed in steps 1 and 2 .

This methodology is currently widely used in data analysis and is reaching new and more challenging possibilities as it integrates the qualitative exploration of messages and information. It is used to describe and interpret the content of all kinds of documents and texts, helping to reinterpret messages and reach an understanding of their meanings at a level that goes beyond ordinary reading (MORAES, 1999). 
After this stage, the data were organized from the matrix of factors following the proposal of Chart 1, which allowed the categorization as follows: a) factors that impact the atmosphere of the environment; $b$ ) factors that need change for physical retail to serve the consumer; c) most important relationships between physical retail and consumer; d) dimension of greater value to the consumer and e) buying behavior.

\section{- Factors that impact the atmosphere of the environment}

The social dimension was more important having as main factors the following: Attendance; Information content; Consumer; Illumination (luminotechnique), as follows:

"Services: Service: Generates synergy respect for the consumer ... Because the human relationship will always be fundamental in the climate of the point of sale..." "Consumer: Wants to be cherished with care and long lasting relationship".

"Light, it is a factor that is linked to our evolutionary history, the luminosity of the environment induces emotional reactions of comfort or discomfort, tranquility or fear, so this will continue to be decisive in the composition of an appropriate climate.

According to respondents, service and experience will be impactful in 2030, as:

"The service is the human bias, importance must be given to the signaling factor and information content based on this service".

"Digital retail will be more developed. Physical stores will play a very important role in the consumer experience as omnichannel will be consolidated."

"Consumer and experience in the spotlight ever and ever."

\section{- Factors that need change for physical retail to serve consumers}

From the collected data, it can be concluded that the social dimension and design need to undergo changes and must evolve to meet new demands, allowing the exposure of new products and promotion of new experiences. Among the factors listed were furniture / layout / experience and signage.

This can also be confirmed in in-depth interviews, in which respondents consider the changes in service and the attractiveness of the place to serve the consumer as fundamental:

"Service is number 1, employees do not represent the brand, they must be part of the consumption journey."

"Physical stores will have to adapt and evolve into a very attractive environment that justifies people going to the points (physical retail)."

"As we are seeing the growing need for experience generation, it will be increasingly important and critical to retail success to change these factors. "

\section{- The most important relationships between physical retail versus consumer}

Regarding the interactions between physical retail and the consumer, the social dimension, represented by personalized service, as well as design, stands out, based on the architecture focused on experience:

"Increasingly the customer seeks quality and fair price in the goods. Don't mind paying more if the service is personalized and efficient."

"Knowing the consumer and treating them differently from on-site experiences will be the most important factors that will attract the public to the POS.".

"Customer focus first, shopping experience as a complement...". 


\title{
- The highest value dimension for consumers
}

The experience dimension, followed by interactivity, are the most important dimensions for the consumer:

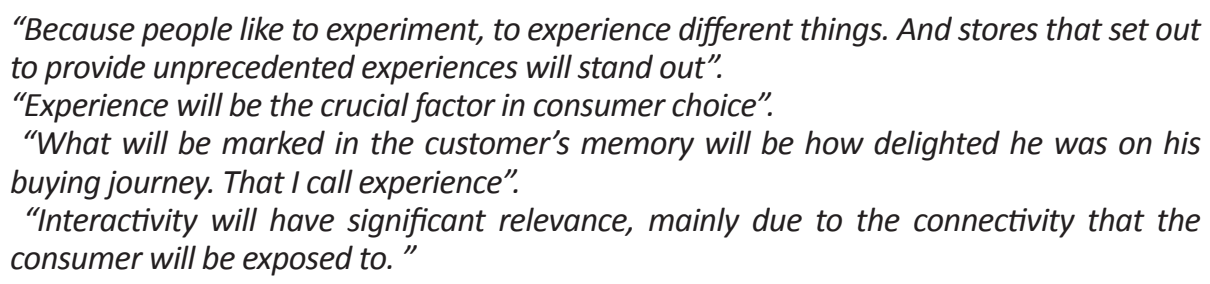

\section{- Purchasing Behavior}

According to the respondents of the two stages, consumer buying behavior will be defined by the social dimension, represented by the personal factor, followed by the influence of the collectivity:

\begin{abstract}
"The first important factor in buying behavior, in my opinion, is social. Possession of a good, most of the time, is to seek acceptance, social inclusion. Once belonging to a clan, the bearer of the good also takes place in the personal field." "We are collecitve beings still and influenced by collective."
\end{abstract}

The social dimension will be present in all atmospheres of the environment in 2030, represented by the attendance factor. This factor provides safety and comfort and puts the consumer in an advantageous position as it defines a contact relationship between the physical retail and the consumer.

As for the factors that need change for the physical retail to serve the consumer, we highlight the attendance factor (social dimension) in view of consumer empowerment through greater access to information and due to technological developments. Thus, the service should be integrated with the design dimension and the signaling factor / information content.

Attention should also be given to building consumer experiences on site and on the buying journey. Respondents advocate an alignment between customer service factor, facility / site attractiveness, and staff so that this experience happens in an organic, without barriers, attractive and determinant way to success.

The consumer will be increasingly informed and will seek high perception of value, to be created through experience and service. Buying behavior will be more personal in the face of empowerment; While social and cultural behavior are important, personal behavior will define purchase and / or acquisition.

\section{CONCLUSION}

This study aimed to discuss the trends related to the environment atmosphere in the Brazilian physical retail in 2030. Thus, we sought to identify how the the environment atmosphere impacts the physical retail and the consumer. Thus, the factors that will influence the atmosphere of the environment were described. It can be seen from the content analysis of the responses of managers interviewed in steps 1 and 2 that, in fact, the physical retail market is changing in the face of technological evolution and with a large information content. As a result, transformations 
are driving significant changes in physical retail and expanding consumer access to information, which will increasingly define how you want your product and / or service. It is evident that the likely atmosphere of the environment in 2030 should be fully integrated, enabling the consumer to have full interactivity with the branded product and / or service. This interaction will have to provide a unique customer experience for them to change their perception of value in an environment of similar pricing and quality. Physical retail will still have to present an atmosphere of the environment with a differential that can be used as a strategy and as a competitive advantage.

\section{BIBLIOGRAPHIC REFERENCES}

ADDIS, M.; HOLBROOK, M. B. On the conceptual link between mass customization and experiencial consumption: an explosion of subjectivity. Journal of Consumer Behaviour, v. 1, n. 1, p. 50-66, 2001. Available on: <http://is.njit.edu/pubs/delphibook>. Acessed on: 8 set. 2017.

ANDERSSON, T. D.; MOSSBERG, L. The dining experience: do restaurants satisfy customer needs? Food Service Technology, v. 4, p. 171-177, 2004.

BÄCKSTRÖM, K.; JOHANSSON, U. Creating and consuming experiences in retail store environments: comparing retailer and consumer perspectives. Journal of Retailing and Consumer Services, v. 13, p. 417-430, 2006.

BAKER, J. et al. The influence of multiple store environment cues on perceived merchandise value and patronage intentions. Journal of Marketing, Birmingham AL, v. 66, n. 2, p. 120-141, 2002.

BERRY, L. L.; CARBONE, P.; HAECKEL, H. O Consumidor e as Experiências. HSM Management, v. 2, n. 37, p. 74-79, 2003.

BITNER, M. J. Servicescapes: the impact of physical surroundings on customers and employees. Journal of Marketing, Birmingham AL, v. 56, n. 2, p. 57-71, Apr. 1992.

BLESSA, R. Merchandising no ponto de venda. 4ạ. ed. São Paulo: Atlas, 2007.

BRYNJOLFSSON, Erik; HU, Yu; RAHMAN, Mohammad S. Competing in the Age of Omnichannel Retailing, MIT Sloan Management Review, 2013.

CARVALHO, J. L. F. S.; MOTTA, P. C. Experiências em cenários temáticos de serviços. Revista de Administração de Empresas, São Paulo, v. 42, n. 2, abr./jun. 2002.

CRESWELL, J. W. Projeto de pesquisa: métodos qualitativo, quantitativo e misto. 3ạ. ed. Porto Alegre: Artmed, 2010.

DAUCÉ, B.; RIEUNIER, S. Le marketing sensoriel du point de vente. Recherche et Applications en Marketing, v. 17, p. 45-65, 2002.

DE ANGELO, C.F.; NIELSEN, F.G.; DIAS FOUTO, N. Manual de varejo no Brasil. São Paulo: Saint Paul, 2012.

FERREIRA, F. N. H. et al. O consumo de experiências em cenários temáticos: um estudo sobre restaurantes de comida japonesa. In: EMA - ENCONTRO DE MARKETING DA ANPAD, 2006, Rio de Janeiro. Anais... Rio de Janeiro: ANPAD, 2006.

GHAURI, P. N.; GRONHAUG, K. Research methods in business studies: A practical guide. New York: Prentice Hall, 1995. 
GIL, A. Como elaborar projetos de pesquisa. 3ạ. ed. São Paulo: Atlas, 2014.

GONZÁLEZ-BENITO, O.; MUÑOZ-GALLEGO, P.; KOPALLEB, P. Asymmetric competition in retail store formats: Evaluating inter- and intra-format spatial effects. Journal of Retailing, Salamanca, v. 81, n. 1, p. 59-73, 2005.Available on: <http://www.focuspesquisa.com.br/novastendencias/umacrise-de-confianca-no-arketing/>. Acessed on Aug.6, 2018.

GRAY, D. E. Pesquisa no mundo real. 2a․ ed. Porto Alegre: Penso, 2012.

HAVLENA, W. J.; HOLBROOK, M. B. The varieties of consumption experience: comparing two typologies of emotion in consumer behavior. Journal of Consumer Research, v. 13, n. 3, 1986.

HETZEL, P. Vers une approche experientielle de la haute cuisine française: lorsque marketing sensoriel rime avec construction du sens. Revue Française du Marketing, v. 196, 2004.

HIRSCHMAN, E.; HOLBROOK, M. B. Hedonic consumption: emerging concepts, methods and propositions. Journal of Marketing, v. 46, n. 3, p. 92-101, 1982.

HOLBROOK, M. B. Consumer value: a framework for analysis and research. Advances in Consumer Research, v. 23, n. 1, p. 138-142, 1996.

HOLBROOK, M. B.; GARDNER, M. P. Illustrating a dynamic model of the mood-updating process in consumer behavior. Psychology e Marketing, v. 17, n. 3, 2000.

KERIN, R. A. et al. Marketing. 8. ed. São Paulo: Mc-Graw-Hill, 2007.

KOTLER, P. Atmospheric as a Marketing Tool. Journal of Retailing, v. 49, n. 4, p. 48-64, 1973.

KOTLER, P.; KELLER, K. L. Administração de marketing. 14. ed. São Paulo: Pearson Prentice Hall, 2012.

LAKSONO, V. L. Pengaruh Shop Environment, Staff, Integrated Marketing Communications, Dan Hedonic Value Terhadap Impulsive Buying PadaKonsumen Carrefour Di Surabaya. KajianllmiahMahasiswaManajemen, v. 2, n. 4, 2013.

MCGOLDRICK, Peter J. Retail marketing, 2. ed. London: McGraw Hill, 2002.

MEHRABIAN, A.; RUSSELL, J. A. An Approach to Environmental Psychology. Cambridge: MIT Press, 1974.

MILAN, G. S. Ampliando o entendimento sobre a emoção existente nas interações de serviços. Revista Brasileira de Gestão e Negócios, v. 9, n. 23, p. 51-60, jan./apr. 2007.

MORAES, Roque. Análise de conteúdo. Revista Educação, Porto Alegre, v. 22, n. 37, p. 7-32, 1999.

NAYLOR, G. et al. Using transformational appeals to enhance the retail experience. Journal of Retailing, v. 84, n. 1, p. 49-57, 2008.

PEREZ, C. Signos da Marca: expressividade e Sensorialidade. São Paulo: Pioneira Thomson Learning, 2004.

PUCCINELLI, N. M. et al. Customer experience management in retailing: understanding the buying process. Journal of Retailing, v. 85, n. 1, p. 15-30, 2009.

QUEIROZ, Renata Steffanoni Bernardes. Estrutura conceitual para avaliação da comunicação em franquias, baseado na criação de experiências para o consumidor no ponto-de-venda. 2015. 185 
f. Tese (Doutorado em Ciências da Comunicação) - Escola de Comunicação e Artes, Universidade de São Paulo. São Paulo, 2015.

REINARTZ, Werner; WIEGAND, Nico. The Perils of Retail Price Differentiation: Why Nobody Wins When Customers Lose. NIM Marketing Intelligence Review, v. 11, n. 1, p. 30-35, 2019.

RICHARDSON, P.; JAIN, A. K.; DICK, A. The influence of store aesthetics on evaluation of private label brands. Journal of Product \& Brand Management, Bingley UK, v. 5, n. 1, 1996.

SAMPIERI, R. H.; COLLADO, C. F.; LUCIO, P. B. Metodologia de Pesquisa. 3a. ed. São Paulo: McGrawHill, 2006.

SCHMITT, B. Experiencial Marketing. Journal of Marketing Management, v. 15, p. 53-67, 1999.

SIQUEIRA, J. P. L. A internet e o varejo: uma análise dos interesses da oferta e da preferência dos consumidores. 2004. Tesis (Doutorado em Administração) - Faculdade de Economia, Administração e Contabilidade, Universidade de São Paulo, 2004.

SOLOMON, M. R. O comportamento do consumidor: comprando, possuindo e sendo. 5a. ed. Porto Alegre: Bookman, 2002.

TEIXEIRA; G, A. K.; BARBOSA, M. L. A. O sistema de oferta de restaurantes de alta gastronomia: uma perspectiva. In: ENCONTRO DA ASSOCIAÇÃO NACIONAL DE PÓS-GRADUAÇÃO E PESQUISA EM ADMINISTRAÇÃO, 2008, Rio de Janeiro. Anais... Rio de Janeiro: ANPAD, 2008.

TURLEY, L. W.; CHEBAT, J.-C. Linking retail strategy, atmospheric design and shopping behaviour. Journal of Marketing Management, Argyll, v. 18, n. 1/2, 2002.

UNDERHILL, P. Vamos às compras: a ciência do consumo nos mercados globais. Rio de Janeiro: Elsevier, 2009.

UNDERHILL, P. A magia dos shoppings: como os shoppings atraem e seduzem. Rio de Janeiro: Elsevier, 2004.

VERDE, A. A. G. F. L.; ARRUDA, D. M. O.; MOURA, H. J. A influência dos estímulos ambientais na satisfação do consumidor em cenário temático, à luz da Teoria Cognitiva das Emoções. In: ENCONTRO DA ASSOCIAÇÃO NACIONAL DE PÓS-GRADUAÇÃO E PESQUISA EM ADMINISTRAÇÃO, 2007, Rio de Janeiro. Anais... Rio de Janeiro: ANPAD, 2007.

VERHOEF, P. C. LEMON, K. N. PARASURAMAN, A. ROGGEVEEN, A. TSIROS, M. SCHLESINGER, L. A. Customer experience creation: determinants, dynamics and management strategies. Journal of Retailing, v. 85, n. 1, p. 31-41, 2009.

VERHOEF, P. C., KANNANB, P.K., INMAN, J. J. "From Multi-Channel Retailing to Omni-Channel Retailing Introduction to the Special Issue on Multi-Channel Retailing", Journal of Retailing, 2, 2015, p. 174-181.

WOODRUFF, R. B. Customer value: the next source of competitive advantage. Journal of Academy of Marketing Science, Coral Gables, v. 25, n. 2, 1997.

ZEITHAML, V. A. Consumer perceptions of price, quality and value: a means-end model and synthesis of evidence. Journal of Marketing, v. 52, p. 2-22, jul. 1988. 


\begin{tabular}{|c|c|c|c|c||}
\hline Contribution & [Author 1] & [Author 2] & [Author 3] & [Author 4] \\
\hline $\begin{array}{c}\text { 1. Definition of research problem } \\
\text { 2. Development of hypotheses or research } \\
\text { questions (empirical studies) }\end{array}$ & $\mathrm{x}$ & & & \\
\hline $\begin{array}{c}\text { 3. Development of theoretical propositions } \\
\text { (theoretical work) }\end{array}$ & $\mathrm{x}$ & & & \\
\hline 4. Theoretical foundation / Literature review & $\mathrm{x}$ & $\mathrm{x}$ & $\mathrm{x}$ & $\mathrm{x}$ \\
\hline 5. Definition of methodological procedures & $\mathrm{x}$ & $\mathrm{x}$ & & \\
\hline 6. Data collection & $\mathrm{x}$ & & & \\
\hline 7. Statistical analysis & $\mathrm{x}$ & $\mathrm{x}$ & $\mathrm{x}$ & \\
\hline 8. Analysis and interpretation of data & $\mathrm{x}$ & & $\mathrm{x}$ & $\mathrm{x}$ \\
\hline 9. Critical revision of the manuscript & & & $\mathrm{x}$ & $\mathrm{x}$ \\
\hline 10. Manuscript writing & $\mathrm{x}$ & & $\mathrm{x}$ & \\
\hline 11. Other (please specify) & & & & \\
\hline
\end{tabular}

